\title{
SATELLITE DATA BASED LANDUSE AND LANDCOVER CHANGE ANALYSIS IN SOUTHEASTERN PART OF PANCHKULA CITY, HARYANA
}

\author{
Anup Kumar ${ }^{1^{*}}$, Shishupal Singh ${ }^{2}$ and V.S. Arya ${ }^{3}$ \\ ${ }^{1}$ Front Office-HARSAC, Sector-2, Panchkula \\ ${ }^{2}$ Govt. ITI, Sector-14, Panchkula \\ ${ }^{3}$ Haryana Space Applications Centre (HARSAC), CCS HAU Campus, Hisar
}

\section{Research Article}

Received: 20.11.2020

Revised: 28.11.2020

\begin{abstract}
Landuse refers to the use of land by human beings while the land cover refers to the natural cover on land. Landuse and land cover mapping is important for better developmental planning purpose. In the present time remote sensing satellite data, geographical information system (GIS) and global positioning system (GPS) are widely used in mapping of land use and land cover. In the present study landuse and land cover change analysis of southeastern part of Panchkula city have been done using Google Earth satellite data of 2002 and 2018. Satellite data downloaded from Google Earth and geo-referenced in ArcGIS 10.4 software.Landuse and landcover classes had been interpreted and field visit was done at selected location to check the interpreted data. Final maps were prepared and area of landuse and land cover classes were calculated. The study shows that during the year 2002 to 2018 built-up land area increased 95.01Hect, agriculture land area increased 1.24Hect., river course area decreased 20.35 Hect., vacant land area decreased 119.43Hect., park area increased 14.64 Hect., open scrub area decreased 7.82 Hect., road area increased 7.21 Hect.,water body area increased 0.02 Hect. and forest area increased $30.48 \mathrm{Hect}$. The study can be used for monitoring land use and land cover for planning purpose in the study area.
\end{abstract}

Keywords: Landuse, landcover, satellite data, Panchkula, Haryana.

\section{INTRODUCTION}

Water is important for survival of all the living beings on the Earth. The present developmental activities have put stress on water quantity and quality. Though water quantity and quality play vital role in the existence of living beings and infrastructure but the role of good quality water is more than quantity of water. In urban areas groundwater is deteriorated due to anthropogenic pollution sources like household sewage waste and industrial waste disposals. Prakash and Somashekar (2006), Deshpande and Aher (2012), Rao et al. (2013), Alhababy et al. (2015), Annapoorna and Janardhana (2015), Spanos et al. (2015), Srinivas et al. (2015), Madhav et al. (2018), Siddiqui et al.
(2018), Hanumantharao, et al. (2019) have studied groundwater quality in urban areas.

\section{STUDY AREA}

The study area Baltanais a part of Zirakpur in Mohali district, Punjab and Sector-19 of Panchkula city in Haryana. Baltana is located at a distance of $2.7 \mathrm{kms}$ from Chandigarh connected by the Zirakpur Panchkula-Kalka highway NH-5. The study area is falling between the latitude $30^{\circ} 40^{\prime} 50.62 " \mathrm{~N}$ to $30^{\circ} 40^{\prime} 6.91$ " $\mathrm{N}$ and longitude76 ${ }^{\circ} 49^{\prime} 18.18 ”$ 'E to 76.50'5.61”Eand covers an area of9.649Km² (Fig 1).Baltana has changed from agriculture sector to residential and industrial sectors.

*Corresponding author: anup0106@yahoo.com 


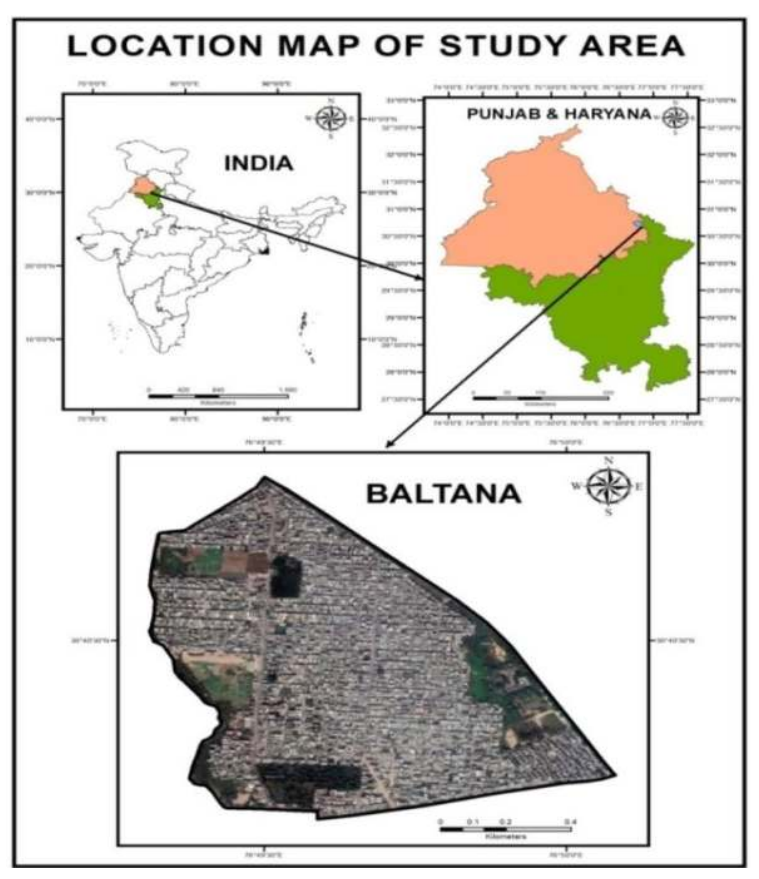

Fig.1: Location map of the study area.

\section{OBJECTIVE}

The main objective was to study land use and land cover change analysis in the study area.

\section{MATERIALS USED AND METHODOLOGY}

Google Erath satellite data for the year 2002 and 2018 and Arc GIS 10.4 software have been used in the study. Google Earth Free satellite data have been downloaded and geo-referenced in Arc GIS software. Satellite data have been interpreted for land use and land cover classes. Field visit was done to check the land use and land cover classes. Final land use and land cover maps have been prepared and area of each land use and land cover class also calculated. Land use and land cover area have been put in excel software and prepared the bar graph.

\section{RESULTS AND DISCUSSION}

The scenario of change in landuse and land cover in the study area aregiven below:

\section{i. Agriculture Land}

Agriculture land area was0.46 Hect.in 2002 and 1.70Hect. in 2018. Agriculture land area increased 1.24Hect. during 2002 to 2018 (Fig.3, Fig.4 and Table 1).

\section{ii. Built-up Land}

Built-up land area was62.35Hect in 2002 and 157.36
Hect in 2018. Built-up land area increased 95.01 Hect. during 2002 to 2018(Fig.3, Fig.4 and Table 1).

\section{iii. Vacant Land}

Vacant land area was295.52 Hect. in 2002 and 176.09 Hect. in 2018. Vacant land areadecreased 119.43Hect. during 2002 to 2018(Fig.3, Fig.4 and Table 1).

\section{iv. Open Scrub}

Open scrub area was49.68 Hect. in 2002 and 41.86 Hect.in 2018. Open scrub areadecreased 7.82Hect. during 2002 to 2018(Fig.3, Fig.4 and Table 1).

\section{v. Park}

Park area was1.35 Hect. in 2002 and 15.99Hect. in 2018. Park area increased 14.64 Hect. during 2002 to 2018(Fig.3, Fig.4 and Table 1).

\section{vi. Forest}

Forest area was37.61Hect. in 2002 and 68.09 Hect. in 2018. Forest area increased 30.48 Hect. during 2002 to 2018(Fig.3, Fig.4 and Table 1).

\section{vii. Road}

Road area was55.87Hect. in 2002 and 62.08 Hect. in 2018. Road area increased 7.21 Hect. during 2002 to 2018(Fig.3, Fig.4 and Table 1).

\section{viii. Water Body}

Water body area was $\mathbf{0 . 2 1}$ Hect. in 2002 and 0.23 Hect. in 2018. Water body area increased 0.02 Hect. during 2002 to 2018(Fig.3, Fig.4 and Table 1).

Table 1: Change in Land use/Land cover Area (2002 to 2018).

\begin{tabular}{|l|l|l|l|}
\hline $\begin{array}{l}\text { Land use/ } \\
\text { Land cover } \\
\text { Classes }\end{array}$ & $\begin{array}{l}\text { Area in } \\
\mathbf{2 0 0 2} \text { (Hect.) }\end{array}$ & $\begin{array}{l}\text { Area in } \\
\mathbf{2 0 1 8} \text { (Hect.) }\end{array}$ & $\begin{array}{l}\text { Change in } \\
\text { Area (Hect.) } \\
\mathbf{2 0 0 2 - 2 0 1 8})\end{array}$ \\
\hline $\begin{array}{l}\text { Agriculture Land } \\
\text { Built-up }\end{array}$ & 0.46 & 1.70 & +1.24 \\
\hline Land & 62.35 & 157.36 & +95.01 \\
\hline Road & 55.87 & 62.08 & +7.21 \\
\hline Park & 1.35 & 15.99 & +14.64 \\
\hline Forest & 37.61 & 68.09 & +30.48 \\
\hline Water Body & 0.21 & 0.23 & +0.02 \\
\hline Vacant Land & 295.52 & 176.09 & -119.43 \\
\hline Open Scrub & 49.68 & 41.86 & -7.82 \\
\hline River & 134.55 & 114.20 & -20.35 \\
\hline Total & 637.60 & 637.60 & \\
\hline
\end{tabular}




\section{ix. River}

River area was134.55 Hect. in 2002 and 114.20 Hect. in 2018. River area decreased 20.35 Hect. during 2002 to 2018 (Fig.3, Fig.4 and Table 1).

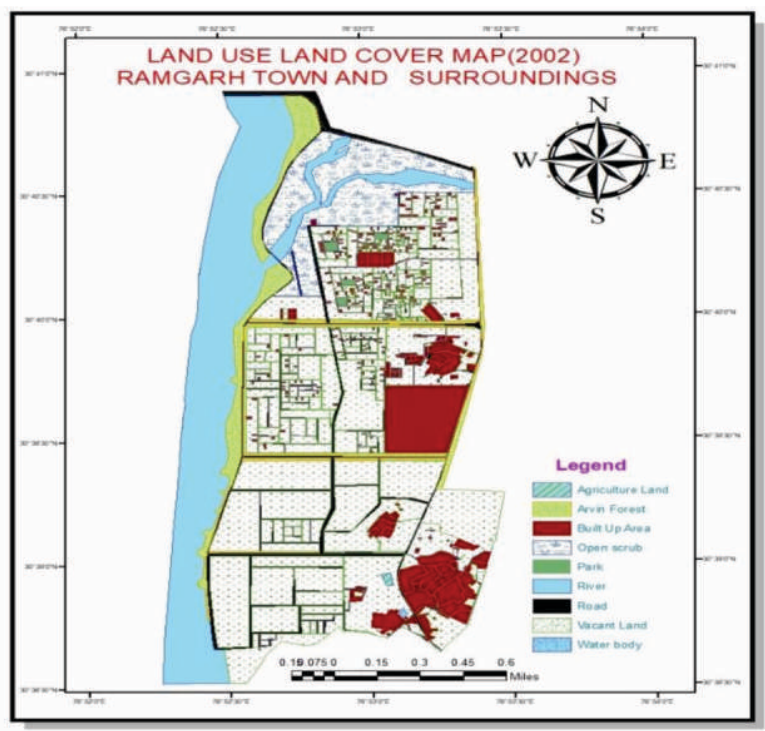

Fig.3: Landuse/landcover map (2002).

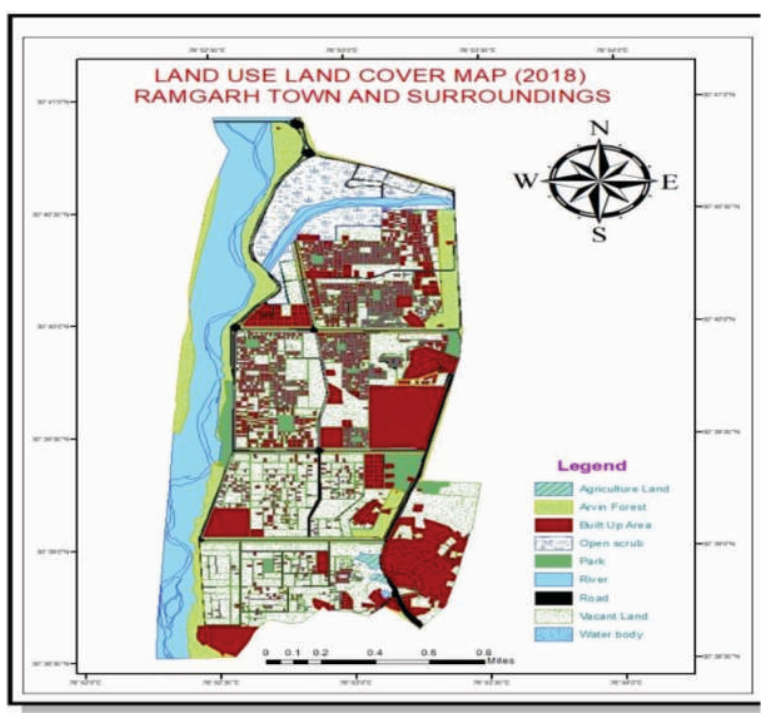

Fig.4: Landuse/landcover map (2018).

\section{CONCLUSIONS}

The study shows that during the year 2002 to 2018 agriculture land area increased 1.24 Hect., river course area decreased 20.35 Hect., vacant land area decreased 119.43Hect., park area increased 14.64 Hect., open scrub area decreased 7.82 Hect., road area increased
7.21 Hect., built-up land area increased 95.01 Hect., water body area increased 0.02 Hect.and forest area increased 30.48 Hect. The study is highly useful for monitoring land use and land cover for planning and management purpose.

\section{ACKMOWLEDGEMENTS}

Authors are duly acknowledged the Google Earth for using their satellite data in the present study.

\section{REFERENCES}

1. Borana, S.L., Yadav,S.K. and Parihar,S.K. (2017).Using remote sensing and GIS to monitor landuse-land cover change in Jodhpur city and surrounding area, InternationalJournal of Innovative Research in Science,Engineering and Technology, 6 (10):20369-20375.

2. Borsah, A.Aidoo, Boah,E.Annan and Adu, A.Ohene (2018). Remote sensing and GIS assisted approach for land cover change detection with respect to elevation: a case study in Tarkwa,Western region of Ghana, The International Journal of Engineering and Sciences,7 (10 verI):61-67.

3. Gajbhiye,S. and Sharma, S.K. (2012).Land use and land cover change detection of Indra river watershed through remote sensing using multitemporal satellite data, International Journal of Geomatics and Geosciences, 3 (1):89-96.

4. Harinadh,M. and Babu,Y.L., Surendra (2017).Preparation of change detection mapping using remote sensing and GIS:a model study, International Journal of Civil Engineering and Technology, 8 (8):1599-1605.

5. Kayet, Narayan and Pathak,Khanindra (2015).Remote sensing and GIS based land use/ land cover change detection mapping in Sarandaforest,Jharkhand, India, International Research Journal of Earth Sciences, 3(10):1-6.

6. Mas, J.F.(1999). Monitoring land cover changes; a comparison of change detection techniques, Int.J. Remote Sensing, 20 (1):139-152.

7. Ranjan, Avinash Kumar, Anand, Akash, Vallisree, S. and Singh, Rahul Kumar (2016). LU/LC change detection and forest degradation analysis in Dalma wildlife sanctuary using 3S Technology: a case study in Jamshedpur, India, AIMS Geosciences, 2 (4):273-285. 
8. Ramamoorthy, P., Sundararaman,S. and Raju,S. (2016). Landuse and land cover change detection using remote sensing and GIS,a case study of Nandhiyar sub basin,Tamil Nadu, India, International Journal of Science \& Engineering, 2 (7):213-216.

9. Soni, Sandeep, Garg,P.K.,Singh,Ashutosh and Maurya,Abhishek,K. (2015).Assessment of land use land cover change in Chakrar watershed using geospatial technique, Tropical Plant Research An International Journal,2(2):101-107.

10. Sreenivasulu, G., Jayaraju, N., Kumar, M. Pramod, Prasad, T. Lakshmi (2013).An analysis on landuse /land cover using remote sensing and GIS-a case study in and around Vempalli, Kadapa District, Andhra Pradesh, India, International Journal of Scientific and Research Publications, 3(1):1-4.

11. Sun, Qiong, Zhang Chi, Liu, Min and Zhang,Yongjing (2016).Landuse and land cover change based on historical space-time model, Solid Earth,7:1395-1403.

12. Usha, M., Anitha, K. and Iyappan, L. (2012). Landuse change detection through image processing and remote sensing approach: a case study of Palladamtaluk, Tamil Nadu, International Journal of Engineering Research and Applications, 2(4):289-294. 